Istanbul Finance Congress, November 1-2, 2018, Istanbul, Turkey.

\title{
RE-VISITING THE TURKISH STOCK MARKET EFFICIENCY: EVIDENCE FROM ADAPTIVE WILD BOOTSTRAP TESTING PROCEDURES
}

\author{
DOI: 10.17261/Pressacademia.2018.977 \\ PAP-IFC- V.8-2018(9)-p.38-42
}

\section{Efe Caglar Cagli}

Dokuz Eylul University, Faculty of Business, Tınaztepe Yerleşkesi Buca/izMiR-35390, Turkey efe.cagli@deu.edu.tr, ORCID: 0000-0002-8250-141X

\section{To cite this document}

Cagli, E. C. (2018). Re-visiting the Turkish stock market efficiency: evidence from adaptive wild bootstrap testing procedures. PressAcademia Procedia (PAP), V.8, p.38-42.

Permanent link to this document: http://doi.org/10.17261/Pressacademia.2018.977

Copyright: Published by PressAcademia and limited licensed re-use rights only.

\begin{abstract}
Purpose - This study aims to test the weak form efficient market hypothesis in Borsa Istanbul (BIST). We analyze weekly price indices, BIST100, BIST-Financials, BIST-Industrials, BIST-Service, and BIST Technology over the period January 1988 - September 2018.

Methodology - In addition to well-known unit root tests, we apply adaptive wild bootstrap testing procedures proposed by Cavaliere et al. (2018) and Boswijk and Zu (2018), both considering the non-stationary volatility process.

Findings - The standard unit root tests provide mixed results. However, Carrion-i-Silvestre et al. (2009) and Maki (2015) unit root tests, and adaptive wild bootstrap testing procedures of both Boswijk and Zu's (2018) and Cavaliere et al. (2018) suggest that all price indices contain unit root at $5 \%$ level.

Conclusion- The Turkish stock market is informationally weak-form efficient. The price indices follow a random-walk process; thus, it is fruitless to conduct trading strategies based on past price information to reap excess returns.
\end{abstract}

Keywords: Market Efficiency, Borsa Istanbul, Unit Root, Long Memory, Adaptive Wild Bootstrap Testing JEL Codes: G32, G40, C23

\section{INTRODUCTION}

The studies on market efficiency can be dated back to early 1900s (Bachelier, 1900; Cowles, 1933). Academics have conducted studies to examine the behavior of stock market prices and observed that the prices are fluctuating randomly (see Mandelbrot, 1963; Samuelson, 1965; Fama, 1965a, 1965b). Fama (1970) formalizes the early ideas, observations and develops efficient market hypothesis. Fama (1970) defines efficient market as "a market in which prices always 'fully reflect available information". Jensen (1978) states that it is impossible make economic profits using the information set in efficient markets.

Since we do not observe information set directly, Fama (1970) proposes three information subsets relevant to the adjustments of security prices in markets: (i) Weak-form efficiency, (ii) semi-strong form efficiency, (iii) strong-form efficiency. In weak-from efficient markets, information set contains only past prices of the securities, thus, it is fruitless to conduct technical analysis to reap positive risk-adjusted returns after accounting transaction costs. The information set in semi-strong form efficient markets contains public fundamental data (e.g. earnings and dividend prospects of corporations) in addition to the past prices, so that trading strategies based on fundamental and technical analyses cannot generate economic profits. Finally, for strong form of efficiency, the information set contains all public and private (insider) information available to any market participant, indicating that the changes in prices are random over time.

A myriad of studies has attempted to test the efficient market hypothesis. Essentially, the studies have checked whether the security prices exhibit random walk or predictable patterns. The studies employ serial correlation tests, runs tests, variance ratio tests, unit root tests, long-memory tests for testing weak-form efficiency (Keim and Stambaugh, 1986; Lo and MacKinlay, 1988, Fama and French, 1988, 1989; Campbell and Shiller, 1988), conduct event studies for testing semi-strong form efficiency (Banz, 1981; Basu, 1983; Blume and Stambaugh, 1983; Fama and French, 1992), and investigate the presence of private information in the security prices for testing strong-form of efficiency (Jaffe, 1974; Givoly and Palmon, 1985; Seyhun, 1986). Following the early studies, a number of empirical studies provide evidence in favor of efficient market hypothesis, while others have suggested rejecting the efficient market hypothesis. This leads academics to test the efficient market hypothesis constantly for different markets, using different methods overcoming the shortcomings of the conventional statistical procedures.

This study aims to test weak form efficient market hypothesis in Turkish stock market, Borsa Istanbul (BIST). There is no consensus on the issue for Borsa Istanbul: Smith and Ryoo (2003), Buguk and Brorsen (2003), Ozdemir (2008), Karan and Kapusuzoglu (2010) and Gozbasi et al. (2014) suggest that Turkish stock market is weak form efficient; Balaban (1995a, 1995b), Demirer and Karan (2002) and Ozer and Ertokatli (2010) provide evidence against the efficient market hypothesis. Our study differs from the previous literature since we employ 
battery of unit root tests, some of which consider integrated volatility process, structural breaks, and nonlinearity in the data. The remainder of the paper is organized as follows: Section 2 describes methodology, Section 3 presents the data and empirical findings, and Section 4 concludes the paper.

\section{METHODOLOGY}

We employ battery of unit root tests to check whether the time-series have a unit root (random walk) or stationary (predictable pattern) over time. The rejection of unit root implies market is not informationally efficient. First three unit root tests we employ are standard unit root tests, Augmented Dickey and Fuller (1979) (ADF), Phillips and Perron (1988) (PP), and Kwiatkowski, Philips, Shin and Schmidt (1992) (KPSS). The null hypothesis of $A D F$ and $P P$ is that the time series contains a unit root, while that of KPSS test is the stationarity.

Given the fact that standard unit root tests lose their power in the presence of a structural break in the deterministic trend, we employ Carrion-i-Silvestre et al.'s (2009) unit root testing procedures which allow for an arbitrary number of changes up to five structural breaks in both the level and slope of the trend function. Following the procedures, we estimate three $M$-type unit root tests, MZA, MSB, and MZT. Each tests the null hypothesis of unit root against the alternative of stationarity.

We also estimate a unit root test in Exponential Smooth Transition Autoregressive (ESTAR) models proposed by Maki (2015) to account for nonlinearities in the data. Maki's (2015) unit root test $(t)$ performs well in the presence of heteroskedastic variances, stochastic volatility by estimating $p$-value of the test through wild bootstrapping. The test tests the null hypothesis of unit root against the alternative of stationarity.

Finally, we employ adaptive wild bootstrap unit root tests of Boswijk and Zu (2018) and adaptive fractional time series models of Cavaliere et al. (2018). Both testing procedures account for integrated volatility process, and non-parametrically adapt to unconditional heteroskedasticity of unknown form. Boswijk and Zu (2018) modify Dickey-Fuller (DF) unit root test and estimate $p$-value of the $L R$ test via wild bootstrapping. The null hypothesis of $L R$ test is unit root against the alternative of stationarity. Cavaliere et al. (2018) estimate the memory parameter $(d)$ in the fractional time series models, using both Quasi-Maximum Likelihood ( $Q M L)$ and Adaptive Conditional Sum-ofSquares (ACSS) estimators, recovering the efficiency losses. We consider testing the hypothesis on the memory parameter, $d=1$ for unit root.

\section{DATA AND EMPIRICAL FINDINGS}

We obtain price indices of BIST-100, BIST Financials (BIST-FIN), BIST Industrials (BIST-IND), BIST Services (BIST-SRV), and BIST Technology (BIST-TEC) from the Electronic Data Delivery System (EDDS) of the Central Bank of the Republic of Turkey (CBRT). We use weekly-frequency data, following the work of Lo and MacKinlay (1988), Buguk and Brorsen (2003). The sample period for all indices ends in September 2018, however the starting point of the sample period is different for price indices: January 1988 for BIST-100, January 1991 for BIST-FIN and BIST-IND, January 1997 for BIST-SRV, and June 2000 for BIST-TEC. We analyze the natural logarithm of the price indices.

Table 1 reports the results of the standard unit root tests, $A D F, P P$, and KPSS. The ADF test statistics suggest that all price indices except BIST-SRV contain unit root. According to PP unit root test statistics, BIST-100, BIST-IND, and BIST-SRV are found to be stationary at $10 \%$ significance level; however, BIST-FIN and BIST-TEC have unit root. The KPSS test statistics suggest rejecting the null hypothesis of stationary at $1 \%$ significance level, indicating that all price indices have unit root. Overall, standard unit root tests provide mixed results for the stationarity of the price indices.

Table 1: Standard Unit Root Tests

\begin{tabular}{|c|c|c|c|}
\hline Index & ADF & PP & KPSS \\
\hline BIST-100 & -2.351 & $-2.617^{c}$ & $4.368^{a}$ \\
\hline BIST-FIN & -2.485 & -2.481 & $3.850^{\mathrm{a}}$ \\
\hline BIST-IND & -2.475 & $-2.647^{c}$ & $4.158^{a}$ \\
\hline BIST-SRV & $-2.572^{c}$ & $-2.815^{c}$ & $4.100^{a}$ \\
\hline BIST-TEC & -0.835 & -0.773 & $3.561^{a}$ \\
\hline
\end{tabular}

Note: a and c denote rejection of null hypothesis at $1 \%$ and $10 \%$ statistical significance levels, respectively.

The estimation results for $M$-type unit root tests by Carrion-i-Silvestre et al. (2009) are reported in Table 2 . We cannot reject the null hypothesis of unit root based on the $M$-type unit root tests, implying that all price indices contain a unit root in the presence of structural breaks which are accumulated around significant financial crises (e.g. economic crises in 1994, 2001 and 2007 ), socio-political events (e.g. Gezi Park protests in May-2013), and government changes (e.g. Justice and Development Party coming to power without the support of a coalition partner just before March-2003).

Table 2: Carrion-i-Silvestre (2009) Unit Root Tests

\begin{tabular}{lrrrr}
\hline Test & BIST-100 & BIST-FIN & BIST-IND & BIST-SRV \\
\hline \hline MZA & -37.612 & -32.032 & -35.065 & -39.867 \\
MSB & 0.115 & 0.124 & 0.119 & -29.756 \\
MZT & -4.336 & -3.986 & -4.186 & -112 \\
\hline Break Points & & & & -4.462 \\
\hline$T B_{1}$ & Feb-91 & Mar-94 & Mar-94 & Jan-00 \\
$T B_{2}$ & Mar-94 & Jan-97 & Oct-97 & Jun-02 \\
$T B_{3}$ & Jan-00 & Dec-99 & Nov-00 & Fec-07 \\
$T B_{4}$ & Mar-03 & Mar-03 & Feb-05 & Dec-07 \\
$T B_{5}$ & Oct-07 & Feb-06 & May-13 & Jul-16 \\
\hline \hline
\end{tabular}


Table 3 reports the results of the Maki (2015) unit root test which account for nonlinearities stemming from market frictions, noise traders, transaction costs, and so forth. The results suggest that all price indices except BIST-SRV have unit root in their level since their bootstrapped $p$-values are estimated higher than conventional statistical significance levels. BIST-SRV is found to be stationary at $10 \%$ statistical significance level.

Table 3: Maki (2015) Unit Root Test

\begin{tabular}{lrrrr}
\hline & BIST-100 & BIST-FIN & BIST-IND & BIST-SRV \\
\hline \hline Test statistics & -2.751 & -2.507 & -2.434 & -3.613 \\
p-value & 0.206 & 0.353 & 0.435 & -1.957 \\
\hline
\end{tabular}

Table 4 reports the results of Boswijk and Zu's (2018) unit root tests, DF-statistics along with their asymptotic and wild bootstrapped $p$ values, and wild bootstrapped $p$-values of $L R$ test statistics. The wild bootstrapped $p$-values of both $D F$ and $L R$ statistics are estimated higher than conventional significance levels, indicating that each price index contains a unit root.

Table 4: Asymptotic and wild bootstrap $p$-values of $D F$ and adaptive $L R$ statistics

\begin{tabular}{|c|c|c|c|c|c|}
\hline & DF-stat & $\begin{array}{c}D F \text { asymptotic } \\
p \text {-value }\end{array}$ & $\begin{array}{c}D F \text { WB } \\
p \text {-value }\end{array}$ & $\begin{array}{c}L R \text { WB } \\
p \text {-value }\end{array}$ & $p$ \\
\hline BIST-100 & 2.056 & 0.991 & 0.999 & 0.996 & 3 \\
\hline BIST-FIN & 1.548 & 0.971 & 0.987 & 0.968 & 3 \\
\hline BIST-IND & 2.198 & 0.994 & 1.000 & 1.000 & 8 \\
\hline BIST-SRV & 1.286 & 0.949 & 0.984 & 0.999 & 9 \\
\hline BIST-TEC & 1.262 & 0.948 & 0.982 & 0.995 & 7 \\
\hline
\end{tabular}

Note: $p$ is the autoregressive order.

Using the fractionally integrated time series models of Cavaliere et al. (2018), we report the $d$ parameter estimates along with their robust standard errors, and both $95 \%$ asymptotic and bootstrapped confidence intervals in Table 5 . The $d$ parameters are estimated close to 1. Based on the ACSS- and QML-based confidence intervals, the unit root null hypothesis $(d=1)$ cannot be rejected at the $95 \%$ level for BISTFIN and BIST-TEC. Moreover, the remaining price indices exhibit higher persistence than a unit root process, and they are also nonstationary and non-mean reverting.

Table 5: The QML and ACSS estimate of $d$ parameter

\begin{tabular}{|c|c|c|c|c|c|c|c|c|c|c|}
\hline & \multirow[b]{2}{*}{$d$} & \multirow[b]{2}{*}{$\operatorname{se}(d)$} & \multicolumn{2}{|c|}{ Asymptotic } & \multicolumn{2}{|c|}{ WB1 } & \multicolumn{2}{|c|}{ WB2 } & \multicolumn{2}{|c|}{ WB3 } \\
\hline & & & $\mathrm{Cl}_{L}$ & $\mathrm{Cl}_{u}$ & $\mathrm{Cl}_{L}$ & $\mathrm{Cl}_{u}$ & $\mathrm{Cl}_{L}$ & $\mathrm{Cl}_{u}$ & $\mathrm{Cl}_{L}$ & $\mathrm{Cl}_{U}$ \\
\hline \multicolumn{11}{|c|}{ BIST-100 $(p=0)$} \\
\hline QML & 1.060 & 0.018 & 1.024 & 1.096 & 1.027 & 1.093 & & & & \\
\hline ACSS & 1.041 & 0.020 & 1.002 & 1.081 & 1.002 & 1.081 & 1.000 & 1.083 & 1.003 & 1.080 \\
\hline \multicolumn{11}{|c|}{ BIST-FIN $(p=0)$} \\
\hline QML & 1.045 & 0.013 & 1.019 & 1.071 & 1.023 & 1.066 & & & & \\
\hline ACSS & 1.035 & 0.021 & 0.994 & 1.075 & 0.993 & 1.076 & 0.996 & 1.073 & 0.993 & 1.077 \\
\hline \multicolumn{11}{|c|}{ BIST-IND $(p=0)$} \\
\hline QML & 1.054 & 0.015 & 1.024 & 1.084 & 1.024 & 1.084 & & & & \\
\hline ACSS & 1.050 & 0.022 & 1.008 & 1.093 & 1.007 & 1.093 & 1.010 & 1.091 & 1.007 & 1.094 \\
\hline \multicolumn{11}{|c|}{ BIST-SRV $(p=1)$} \\
\hline QML & 1.027 & 0.012 & 1.005 & 1.050 & 1.005 & 1.050 & & & & \\
\hline ACSS & 1.029 & 0.011 & 1.008 & 1.050 & 1.007 & 1.051 & 1.007 & 1.051 & 1.007 & 1.051 \\
\hline \multicolumn{11}{|c|}{ BIST-TEC $(p=0)$} \\
\hline QML & 0.999 & 0.001 & 0.997 & 1.000 & 0.997 & 1.000 & & & & \\
\hline ACSS & 1.020 & 0.017 & 0.986 & 1.053 & 0.980 & 1.059 & 0.984 & 1.055 & 0.982 & 1.057 \\
\hline
\end{tabular}

Note: $d$ is the memory parameter. se $(d)$ is the (robust) standard error. Wild-bootstrap-1 (WB1) does not re-estimate time-varying scale factor ( $\left.\sigma_{t}\right)$ for each bootstrap replication; WB2 re-estimates $\sigma_{t}$ for each bootstrap replication, estimating the bandwidth parameter in each bootstrap replication using crossvalidation; WB3 re-estimates $\sigma_{t}$ for each bootstrap replication using same bandwidth parameter as selected. $p$ is selected based on forward search algorithm, increasing $p$ by one until the additional lag is estimated statistically insignificant at $10 \%$ level. $\mathrm{Cl}_{L}$ and $\mathrm{Cl}_{U}$ stand for the lower and upper limits of the $95 \%$ confidence intervals.

\section{CONCLUSION}

The above econometric methods by Boswijk and Zu (2018) and Cavaliere et al. (2018) are employed for the first time to examine the weak form efficiency of the Turkish stock market. Overall results show that BIST-100 and sector price indices have a unit root. Particularly, some sector price indices exhibit higher persistence than a unit root process, they are non-stationary and non-mean reverting. The results may imply that the price indices follow a random-walk process; thus, it is fruitless to conduct trading strategies based on past price information to reap excess returns. We conclude that the Turkish stock market is informationally weak-form efficient in terms of Fama (1970), consistent with the findings of Smith and Ryoo (2003), Buguk and Brorsen (2003), Ozdemir (2008), Karan and Kapusuzoglu (2010), Gozbasi et al. (2014). 


\section{REFERENCES}

Bachelier, L. (1900). Théorie de la spéculation. Gauthier-Villars.

Balaban, E. (1995a). Informational efficiency of the Istanbul Securities Exchange and some rationale for public regulation. The Central Bank of the Republic of Turkey Research Department Discussion Paper, 9502, 39-67.

Balaban, E. (1995b). Some empirics of the Turkish stock market. The Central Bank of the Republic of Turkey Research Department Discussion Paper, (9508).

Banz, R. W. (1981). The relationship between return and market value of common stocks. Journal of financial economics, 9(1), 3-18.

Basu, S. (1983). The relationship between earnings' yield, market value and return for NYSE common stocks: Further evidence. Journal of financial economics, 12(1), 129-156.

Blume, M. E., \& Stambaugh, R. F. (1983). Biases in computed returns: An application to the size effect. Journal of Financial Economics, $12(3), 387-404$.

Boswijk, H. P., \& Zu, Y. (2018). Adaptive wild bootstrap tests for a unit root with non-stationary volatility. The Econometrics Journal, 21(2), 87-113.

Buguk, C., \& Brorsen, B. W. (2003). Testing weak-form market efficiency: Evidence from the Istanbul Stock Exchange. International review of financial analysis, $12(5), 579-590$.

Campbell, J. Y., \& Shiller, R. J. (1988). The dividend-price ratio and expectations of future dividends and discount factors. The Review of Financial Studies, 1(3), 195-228.

Carrion-i-Silvestre, J. L., Kim, D., \& Perron, P. (2009). GLS-based unit root tests with multiple structural breaks under both the null and the alternative hypotheses. Econometric theory, 25(6), 1754-1792.

Cavaliere, G., Nielsen, M., \& Taylor, A. M. (2017). Adaptive inference in heteroskedastic fractional time series models (No. 1390). Queen's University, Department of Economics.

Cowles A. (1933). Can Stock Market Forecasters Forecast? Econometrica, 1(3), 309-324.

Demirer, R., \& Karan, M. (2002). An Investigation of the Day-of-the-Week Effect on Stock Returns in Turkey. Emerging Markets Finance \& Trade, 38(6), 47-77.

Dickey, D. A., \& Fuller, W. A. (1979). Distribution of the estimators for autoregressive time series with a unit root. Journal of the American statistical association, 74(366a), 427-431.

Fama, E. F. (1965a). Random Walks in Stock Market Prices. Financial Analysts Journal, 21(5), 55-59.

Fama, E. F. (1965b). The behavior of stock-market prices. The journal of Business, 38(1), 34-105.

Fama, E. F. (1970). Efficient capital markets: A review of theory and empirical work. The journal of Finance, 25(2), 383-417.

Fama, E. F., \& French, K. R. (1988). Dividend yields and expected stock returns. Journal of financial economics, 22(1), 3-25.

Fama, E. F., \& French, K. R. (1989). Business conditions and expected returns on stocks and bonds. Journal of financial economics, 25(1), 2349.

Fama, E. F., \& French, K. R. (1992). The cross-section of expected stock returns. The Journal of Finance, 47(2), 427-465.

Givoly, D., \& Palmon, D. (1985). Insider trading and the exploitation of inside information: Some empirical evidence. Journal of business, 58(1), 69-87.

Gozbasi, O., Kucukkaplan, I., \& Nazlioglu, S. (2014). Re-examining the Turkish stock market efficiency: Evidence from nonlinear unit root tests. Economic Modelling, 38, 381-384.

Jaffe, J. F. (1974). Special information and insider trading. The Journal of Business, 47(3), 410-428.

Jensen, M. C. (1978). Some Anomalous Evidence Regarding Market Efficiency. Journal of Financial Economics, 6(2/3), 95-101.

Karan, M. B., \& Kapusuzoglu, A. (2010). An analysis of the random walk and overreaction hypotheses through optimum portfolios constructed by the nonlinear programming model. Australian Journal of Basic and Applied Sciences, 4(6), 1215-1220.

Keim, D. B., \& Stambaugh, R. F. (1986). Predicting returns in the stock and bond markets. Journal of financial Economics, 17(2), 357-390.

Kwiatkowski, D., Phillips, P. C., Schmidt, P., \& Shin, Y. (1992). Testing the null hypothesis of stationarity against the alternative of a unit root: How sure are we that economic time series have a unit root?. Journal of econometrics, 54(1-3), 159-178.

Lo, A. W., \& MacKinlay, A. C. (1988). Stock market prices do not follow random walks: Evidence from a simple specification test. The review of financial studies, 1(1), 41-66.

Maki, D. (2015). Wild bootstrap tests for unit root in ESTAR models. Statistical Methods \& Applications, 24(3), 475-490. 
Mandelbrot, B. (1963). The Variation of Certain Speculative Prices. The Journal of Business, 36(4), 394-419.

Ozdemir, Z. A. (2008). Efficient market hypothesis: evidence from a small open-economy. Applied Economics, 40(5), 633-641.

Özer, G., \& Ertokatli, C. (2010). Chaotic processes of common stock index returns: An empirical examination on Istanbul Stock Exchange (ISE) market. African Journal of Business Management, 4(6), 1140-1148.

Phillips, P. C., \& Perron, P. (1988). Testing for a unit root in time series regression. Biometrika, 75(2), 335-346.

Samuelson, P. A. (1965). Rational theory of warrant pricing. Industrial Management Review, Industrial Management Review, 6(2), 13-39.

Seyhun, H. N. (1986). Insiders' profits, costs of trading, and market efficiency. Journal of financial Economics, 16(2), $189-212$.

Smith, G., \& Ryoo, H. J. (2003). Variance ratio tests of the random walk hypothesis for European emerging stock markets. The European Journal of Finance, 9(3), 290-300. 